\title{
Perceptions of Sexual Discrimination, Sexual Harassment and Job Satisfaction among Female Employees in the Public Sector
}

\section{H E Brand and M T Silberman}

\section{Department of Human Resources Management, University of Pretoria}

\section{ABSTRACT}

Discrimination against women is a phenomenon still present in today's society. While research concerning sexual discrimination has been done, very little has been written about it under South African conditions, and almost no research has been done concerning the perceptions of female employees regarding sexual discrimination and harassment towards them. This study investigated female employees' perception of sexual discrimination, sexual harassment and job satisfaction. A questionnaire was developed and used as a measuring instrument on a probability sample of female employees in a public sector department. Results show that the respondents do not experience sexual discrimination to a large extent, and that they believe that sexual harassment will have a negative effect on job satisfaction, absenteeism and negativity towards the work environment.

JEL J16, J71, M13

\section{INTRODUCTION}

Together with race and class, gender serves as one of the basic reference points around which almost every society is organised (Card, 1999). Being born male or female, fundamentally shapes peoples' lives and plays a major role in determining emotions, personality traits, identity and responsibilities people expect to assume (Card, 1999).

While the entry of women into the higher-paid, male-dominated occupations and jobs has increased, most men still feel that women do not have the required skills to become their equals, and even more so, to become their supervisors or managers (Bews, 1989). According to Bews (1989) the problem with most organisations is that, while managers claim to run equal opportunities organisations, many are just paying lip-service to the elimination of gender 
discrimination and do not institute real changes to accommodate women on an equal level with men in the corporate world.

Discrimination against women in an organisation may lead to a lowering in productivity, increase in labour turnover and a decrease in profits (Sinclair, 1996). Sexual discrimination may also lead to such extreme consequences as law suits against the organisation (Rantalaiho \& Heiskanen, 1997).

While employers today are providing more equal opportunities to their employees, these are often perceived by female employees as mere token attempts to achieve minimal compliance with equal opportunity policies, rather than a true commitment to end sexual discrimination (Powell, 1989). Erwee (1989) concludes that little advancement has been made regarding equal opportunities for women in organisations, due to the fact that such a strategy often implies a painful change in the structure, culture and operations of the organisation.

Discrimination can be described as the denial of equality. It is a set of negative behavioural actions directed at the members of some distinct social group (Bubeck, 1995). Stereotypes consist of information and beliefs about specific groups, and are essentially negative in nature (Slabbert, 1990). Mercer (1986) defines equal opportunity as respect for the individual person as a distinct or unique human being, not to be confused with others because of race, religion or gender.

In South Africa, from a legal point of view, the state is defined as sovereign, non-racial and non-sexist in its new Constitution. The principle of equality on the basis of gender and race is accordingly at the centre of the new constitutional dispensation. Equality of race and gender is also guaranteed in the Bill of Rights. This dual recognition of race and gender in the Constitution accepts that inequality and discrimination in South Africa have often been based on both race and gender and not only on race or gender (Albertyn \& White, 1994).

Although sexual harassment also happens outside the workplace, it is more difficult to avoid the harasser in the workplace. Many women eventually resign jobs solely in an attempt to avoid the harasser (Renwick, 1994). Some still consider sexual harassment of women as an office joke, or allege that women bring it upon themselves. Some men even regard it as a fringe benefit to which their position, power and gender entitle them (Prekel, 1989). Sexual harassment is often about the abuse of power (Broomberg, 1993).

Broadly defined, sexual harassment is unwanted behaviour of a sexual nature which has a negative effect on the recipient, and can be verbal, non-verbal or 
physical (Lubbe, 1995). According to Lubbe (1995), the various behaviours covered by legal definitions of sexual harassment, are:

- Verbal: threats, rude and abrasive remarks, sexist jokes, noises, sexual propositions and demeaning references to women.

- Non-verbal: leering, whistling, offensive pornography, unwanted sexual letters and continued pressure for sex/dates.

- Physical: unwelcome touching, patting, pinching, obscene gestures, assault and indecent exposure.

According to the Equal Employment Opportunity Commission, a more general definition of sexual harassment would be: unwelcome sexual advances, requests for sexual favours and other verbal or physical conduct of a sexual nature (Finnemore, 1998).

As human beings, employees in the workplace have thoughts and feelings that strongly influence their behaviour in a job situation. These thoughts and feelings are part of their conscious states and provide the inputs by them to make decisions about their actions and reactions to their jobs. These conscious states are known as attitudes and beliefs (McCormick \& Ilgen, 1987). Job satisfaction is a specific subset of attitudes held by employees and can be defined as the favourableness or unfavourableness with which employees view their work (Werther \& Davis, 1985).

Employees' attitudes serve several functions. They provide information about employees' reactions to other individuals, events or objects; they guide behaviour; they are even related to the physical and mental health of employees (McCormick \& Ilgen, 1987).

Many of the conditions or factors that lead employees to hold positive or negative views of their jobs have been identified through research. These are highly varied in nature, and are not easily summarised. However, according to Baron \& Greenberg (1990), most seem to fall into three major categories, namely:

1. Factors relating to organisational policies and/or procedures.

2. Factors relating to specific aspects of jobs or the settings in which they are performed.

3. Factors relating to personal characteristics of employees.

It is clear that issues such as gender discrimination and sexual harassment in the workplace could form part of these categories of factors that influence employee attitudes and job satisfaction. 


\section{THIS STUDY}

Perceptions play an important role in any organisation, as they influence the attitudes, behaviour and even loyalty of employees towards the organisation. Thus it should be important and of value to any modern organisation to determine how women employees perceive the male and female workforce, the expectations female employees have, the extent to which discrimination and harassment against women are perceived to be present, as well as the nature and extent of side-effects negative perceptions could have in the work environment.

The purpose of this study, therefore, is to determine the extent to which women perceive discrimination and harassment to be present in a public sector department, as well as their perceptions of job satisfaction.

\section{Research Method}

The research method followed in this study is discussed under the headings of research strategy, research group, sample, and data analysis.

\section{Research Strategy}

This study made use of the survey method, to determine the perceptions of women employees in a public sector department with regard to sexual discrimination, harassment and the possible influences of these aspects on job satisfaction. A standardised questionnaire, developed by Silberman (1991), and using a 5-point Likert scale, was applied to a probability sample of 100 respondents from the specific department's population. The questionnaires were distributed together with an information brochure, indicating the motivation for and characteristics of the study, as well as all relevant instructions. The employees were also informed that the study was conducted with the approval and support of the department's top management.

The following are the particulars of this questionnaire:

The instrument consisted of 84 questions, divided into two main sections with certain components, namely section 1: biographical data, sexual discrimination and sexual harassment, and section 2: job satisfaction. The 5-point Likert-scale used for the evaluation of the items, was applied as follows:

Respondents used five response categories, namely: strongly agree, agree, uncertain, disagree and strongly disagree. 
For favourable statements or items, the strongly agree response was given a weight of 4 , the agree response a weight of 3 , the uncertain response a weight of 2 , the disagree response a weight of 1 and the strongly disagree response a weight of 0 .

For unfavourable statements or items, the above mentioned weighting system was reversed.

Approximately half the items of the questionnaire were favourable, to balance the number of unfavourable items. The advantage of having both these categories of items in the questionnaire, is to minimise possible response sets of subjects that might be generated if only or a majority of favourable or unfavourable items were included in the instrument.

Due to the personal nature of the topics covered in the questionnaire, the survey was conducted anonymously.

The questionnaire was assessed by a panel of experts from the University of Pretoria. The appropriateness of the empirical indicators (questions), as well as the content validity thereof, was confirmed by the panel.

The reliability of the questionnaire was determined with the aid of the SPSS Computer Package (Morgan \& Griego, 1998). An alpha coefficient of 0.66 for section 1 , and 0.96 for section 2 of the questionnaire was obtained.

\section{Research Group}

The research group consists of female employees of a national, public sector department.

\section{Sample}

A probability sample of 100 female employees from a total female employee population of 350 was used for this study. The 100 respondents were drawn by (after making a random start) selecting every $12^{\text {th }}$ person within an alphabetically ordered sampling frame list.

\section{Data Analysis}

After the questionnaires were completed by the respondents, the data was captured in order to obtain statistical information for analysis and interpretation. The data derived from the questionnaires was analysed by means of descriptive 
and inferential statistics of the SPSS Windows computer programme (Morgan \& Griego, 1998).

The frequency distribution of the biographical variables is displayed in the tables below. In the evaluation of the questionnaire data, various statistical methods were used, of which only the results of one-way analysis of variance and frequency distributions will be reported in this article.

\section{Results of the Study}

Description of the sample: The frequency distributions of the biographical variables are presented in Tables 1 to 5.

\section{Table 1 Marital status}

\begin{tabular}{|l|c|c|c|}
\hline Marital status & Frequency & Per cent & $\begin{array}{c}\text { Cumulative } \\
\text { per cent }\end{array}$ \\
\hline Single & 27 & 27.0 & 27.0 \\
Married & 55 & 55.0 & 82.0 \\
$\begin{array}{l}\text { Divorced or } \\
\text { widowed }\end{array}$ & 18 & 18.0 & 100.0 \\
\hline Total & 100 & 100 & \\
\hline
\end{tabular}

According to Table 1, the majority of the sample are married women.

\section{Table 2 Age group}

\begin{tabular}{|l|c|c|c|}
\hline \multicolumn{1}{|c|}{ Age group } & Frequency & Per cent & $\begin{array}{c}\text { Cumulative } \\
\text { per cent }\end{array}$ \\
\hline Under 30 & 53 & 53.0 & 53.0 \\
\hline Over 30 & 47 & 47.0 & 100.0 \\
\hline Total & 100 & 100 & \\
\hline
\end{tabular}

According to Table 2, the majority of the sample are under the age of thirty years. 


\section{Table 3 Educational level}

\begin{tabular}{|l|c|c|c|}
\hline $\begin{array}{c}\text { Educational } \\
\text { level }\end{array}$ & Frequency & Per cent & $\begin{array}{c}\text { Cumulative } \\
\text { per cent }\end{array}$ \\
\hline Grade 12 (matric) & 49 & 51.6 & 51.6 \\
\hline Other & 46 & 48.4 & 100.0 \\
\hline Total & 100 & $100.0(95)$ & \\
\hline No data & 5 & & \\
\hline
\end{tabular}

According to Table 3, the majority of the sample have matriculated, but have not obtained tertiary qualifications.

Table 4 Length of service

\begin{tabular}{|l|c|c|c|}
\hline $\begin{array}{c}\text { Length of } \\
\text { service }\end{array}$ & Frequency & per cent & $\begin{array}{c}\text { Cumulative } \\
\text { per cent }\end{array}$ \\
\hline $1-6$ years & 58 & 59.2 & 59.2 \\
$7+$ years & 40 & 40.8 & 100.0 \\
\hline Total & 100 & $100.0(98)$ & \\
\hline No data & 2 & & \\
\hline
\end{tabular}

According to Table 4, the majority of the sample have worked in the department for less than six years.

Table 5 Job category

\begin{tabular}{|l|c|c|c|}
\hline Job category & Frequency & Per cent & $\begin{array}{c}\text { Cumulative per } \\
\text { cent }\end{array}$ \\
\hline $\begin{array}{l}\text { Clerical } \\
\text { Management } \\
\text { levels }\end{array}$ & 57 & 57.0 & 57.0 \\
\hline Total & 43 & 43.0 & 100.0 \\
\hline
\end{tabular}

According to Table 5 , the majority of the sample occupy clerical positions. Management levels consist of employees with tertiary qualifications.

One-way Analysis of Variance: The results of this analysis are shown in Table 6. Only the results of those variables with statistically significant differences among the various groups will be discussed. 
Table 6 One-way analysis of variance

\begin{tabular}{|c|c|c|}
\hline Variable by MAR & F-value & P-value \\
\hline $\begin{array}{l}\text { Sexual discrimination: } \\
\text { Blamed unfairly } \\
\text { Same benefits } \\
\text { Problem solving } \\
\text { Promotion } \\
\text { Paternalistic } \\
\text { Support } \\
\text { Leadership } \\
\end{array}$ & $\begin{array}{l}3.0103 \\
8.2720 \\
0.0818 \\
3.2825 \\
5.4327 \\
3.1030 \\
1.2411 \\
\end{array}$ & $\begin{array}{l}0.0539 \\
0.0005 * \\
0.9215 \\
0.0417 * \\
0.0058 * \\
0.1276 \\
0.2936 \\
\end{array}$ \\
\hline $\begin{array}{l}\text { Sexual harassment: } \\
\text { Job benefits } \\
\text { Submission } \\
\text { Directorate } \\
\text { Leave me alone } \\
\text { Morale } \\
\text { Absenteeism } \\
\text { Productivity } \\
\text { Performance } \\
\text { Satisfaction } \\
\text { Image of department } \\
\text { Less respect } \\
\text { Negative attitude } \\
\text { Less confidence } \\
\text { Law } \\
\text { Power } \\
\text { Victims \& harassers } \\
\text { Legitimate } \\
\text { Counsellors } \\
\text { Report } \\
\text { Aware } \\
\text { Action } \\
\text { Position }\end{array}$ & $\begin{array}{l}0.8949 \\
3.6072 \\
2.9313 \\
1.5446 \\
1.8982 \\
7.9497 \\
1.8380 \\
2.6868 \\
8.3280 \\
9.5572 \\
3.5437 \\
9.2566 \\
3.0698 \\
1.8991 \\
0.6768 \\
2.3050 \\
1.4146 \\
0.9751 \\
0.4118 \\
0.2471 \\
0.4118 \\
0.5294 \\
\end{array}$ & $\begin{array}{l}0.4120 \\
0.0308 * \\
0.0581 \\
0.2186 \\
0.1554 \\
0.0006 * \\
0.1646 \\
0.0732 \\
0.0005^{*} \\
0.0002 * \\
0.0327 * \\
0.0002 * \\
0.0510 \\
0.1552 \\
0.5106 \\
0.1052 \\
0.2480 \\
0.8897 \\
0.6702 \\
0.7844 \\
0.6702 \\
0.6003\end{array}$ \\
\hline $\begin{array}{l}\text { Job Satisfaction: } \\
\text { Job security } \\
\text { Gross pay } \\
\text { Pay } \\
\text { Personal growth } \\
\text { Quitting } \\
\text { Respect } \\
\text { Excuse } \\
\text { Worthwhile accomplishment } \\
\text { Type of job } \\
\text { Support } \\
\end{array}$ & $\begin{array}{l}5.0584 \\
1.3046 \\
1.8701 \\
2.7178 \\
5.5724 \\
5.3146 \\
4.4845 \\
0.9878 \\
2.7828 \\
4.0922 \\
\end{array}$ & $\begin{array}{l}0.0082^{*} \\
0.2760 \\
0.1597 \\
0.0712 \\
0,0051^{*} \\
0.0065^{*} \\
0.0137^{*} \\
0.3761 \\
0.0668 \\
0.0197^{*}\end{array}$ \\
\hline
\end{tabular}


Table 6 continued

\begin{tabular}{|l|l|l|}
\hline \multicolumn{1}{|c|}{ Variable by MAR } & F-value & P-value \\
\hline Encourage & 0.6251 & \\
Independent thought & 1.5702 & 0.5373 \\
Suggestions & 3.3746 & 0,2132 \\
Challenges & 1.4835 & $0.0383^{*}$ \\
Accomplishment & 0.5988 & 0.2319 \\
Choice & 4.2379 & 0.5515 \\
Quality of supervision & 2.4049 & $0.0172^{*}$ \\
Different supervision & 3.2710 & $0,0372^{*}$ \\
Attitude to people & 2.1658 & $0.0422^{*}$ \\
Example of fellow employees & 1.0226 & 0.1202 \\
Attitude - furure & 0.6423 & 0.3635 \\
& & 0.5283 \\
\hline Quit: & 2.8525 & \\
Satisfied & 2.8721 & 0.0626 \\
Supervisor traits & 5.0262 & 0.0615 \\
Supervisor dealings & 0.5743 & $0.0084^{*}$ \\
Recognition & 1.8083 & 0.5650 \\
Day never ends & 4.0889 & 0.1694 \\
Friend & 1.5899 & $0.0198^{*}$ \\
Enjoy & 6.0763 & 0.2093 \\
Earnings & 1.0373 & $0.0033^{*}$ \\
Force & 4.1580 & $0.3583^{*}$ \\
Trust & 4.0417 & $0.0185^{*}$ \\
Happier than colleagues & 4.4078 & $0.0206^{*}$ \\
& & $0.0147^{*}$ \\
\hline
\end{tabular}

$* \mathrm{P} \leq 0.05$

Table 6 indicates the following results regarding sexual discrimination;

Same benefits:

With regard to the receipt of the same benefits as their male counterparts occupying the same job category, married women seem to differ significantly from divorced/widowed women.

\section{Promotion:}

With regard to whether the respondents rate their prospects of being promoted to a higher position within the next three years as very good, group 2 (married women) differs significantly from group 3 (divorced/widowed women). Judged according to response frequencies on the 5-point Likert scale, it seems that the majority of married women ( 47.3 per cent) do not rate their prospects of being 
promoted to a higher position as very good, while the majority of divorced/widowed women (52 per cent) do.

\section{Paternalism:}

With regard to being treated paternalistically by their supervisors, group 3 (divorced/widowed) differs significantly from group 1 (single) and group 2 (married). It appears that the majority of both single (66.6 per cent) and married ( 56.3 per cent) women have never been treated patemalistically by their supervisors, while the majority of divorcees/widows (55.6 per cent) believe that they are treated in a paternalistic fashion.

The following results regarding sexual harassment have been reported:

\section{Submission:}

Regarding the use of a woman's submission to/rejection of sexual advances by a person in a higher position as a basis for employment decisions affecting ber, group 1 (single) differs significantly from group 3 (divorced/widowed).

The majority of single women (63 per cent) seem to agree that a woman's submission to or rejection of sexual advances by a person of higher authority may be used as a basis for employment decisions affecting them, while the majority of divorcees/widows (61.1 per cent) disagreed.

\section{Absenteeism:}

With regard to sexual harassment affecting absenteeism, group 1(single) differs significantly from group 2 (married) and group 3 (divorced/widowed). The majority of single women (51.9 per cent) appear to feel more strongly than married (27.3 per cent), divorced or widowed women (22.3 per cent), that women experiencing sexual harassment will tend to stay away from work more often in order to avoid such experiences.

\section{Satisfaction:}

With regard to the question whether women who are experiencing sexual harassment have less satisfaction in their work than the average female employee, group 1 (single) differs significantly from group 2 (married) and group 3 (divorced/widowed). It appears that all the single women (100 per cent), in comparison to 25 per cent of the married women and 16.7 per cent of the divorcees/widows, believe that women experiencing sexual harassment will probably have less work satisfaction than the average woman. 
Image of department:

With regard to the question whether women who are experiencing sexual harassment have a negative image of the department, group 1 (single) differs significantly from group 2 (married) and group 3 (divorced/widowed). It appears that more than half of the single women ( 52 per cent), in comparison to less than 25 per cent of the married women and only 16.7 per cent of the divorcees/widows, believe that those women experiencing sexual harassment will probably have a negative image of the department.

\section{Respect;}

Regarding the question whether women who experience sexual harassment have less respect for people in power positions who "turn a blind eye", group 1 (single) differs significantly from group 3 (divorced/widowed). While nearly 60 per cent of single women appear to strongly believe that women in the department who are experiencing sexual harassment will have less respect for people in power positions who turn a blind eye, only about 25 per cent of divorcees/widows believe the same.

\section{Negative attitude:}

With regard to whether women who are sexually harassed have a negative attitude towards their work environment, group 1 (single) differs significantly from both group 2 (married) and group 3 (divorced/widowed). It appears that the majority of single women (51.9 per cent), in comparison to 25.5 per cent of married women and 11.1 per cent of divorcees/widows, strongly believe that women who are experiencing sexual harassment will have a negative attitude towards their work environment.

The results regarding job satisfaction are as follows:

\section{Job security:}

It was found that, regarding satisfaction with job security, group 2 (married) differs significantly from group 1 (single) and group 3 (divorced/widowed). It appears that the majority of group 1 (single) (76.7 per cent) and group 3 (divorced/widowed) (66.7 per cent) are satisfied with the amount of job security they have in the department. Only 45.3 per cent of group 2 (married) indicated that they experience job security. 


\section{Quitting:}

With regard to whether they would consider quitting their job, group 1 (single) differs significantly from group 2 (married) and group 3 (divorced/widowed).

It appears that married women ( 38.2 per cent) generally more often think of quitting their jobs than single women (29.6 per cent) and divorcees/widows (23.5 per cent).

Respect:

With regard to their being satisfied with the degree of respect received from their managers, group 2 (married) differs significantly from group 3 (divorced/widowed). It appears that 22.2 per cent of divorcees/widows are very satisfied with the degree of respect received from their managers, while only 5.5 per cent of married women feel the same.

Excuses (to stay away from work):

With regard to the question whether they would seize a plausible excuse to stay away from work, group 1 (single) differs significantly from group 2 (married) and group 3 (divorced/widowed). It appears that the majority of all three groups (group 1: 55.5 per cent; group 2: 83.6 per cent; group 3: 100 per cent) would not usually seize a plausible excuse to stay away from work.

\section{Support:}

With regard to whether they were satisfied with the amount of support and guidance received from supervisors, group 2 (married) differs significantly from group 3 (divorced/widowed). It appears that the majority of married women (61.9 per cent) are not satisfied with the support and guidance received from their supervisors, while the majority of divorcees/widows (72.2 per cent) are.

Suggestions:

On the question whether they believe that many good suggestions are "killed" by supervisors, group 1 (single) differs significantly from group 3 (divorced/widowed). It appears that the majority of single women (66.6 per cent) believe that many good suggestions are "killed" by their supervisors, while less than half of the divorcees/widows ( 44.5 per cent) agreed with this. 


\section{Choice:}

With regard to the question whether they would choose to work for the department if they could do it over again, group 1 (single) differs significantly from group 3 (divorced/widowed). It appears that the majority of divorcees/widows ( 77.7 per cent) would still choose to work for the department if they had to do it all over again, while only 44.4 per cent of the single women would do so.

\section{Quality of supervision:}

With regard to whether they were satisfied with the overall quality of supervision received, group 2 (married) differs significantly from group 3 (divorced/widowed). It appears that even though the majority of both groups agree that they are satisfied with the overall quality of supervision received in their jobs, the divorcees/widows are more satisfied ( 77.8 per cent) than the single women ( 40 per cent).

\section{Different supervision:}

On the question whether overall job satisfaction in each directorate was influenced by how they were treated by the supervisors, group 1 (single) differs significantly from group 3 (divorced/widowed). It appears that the majority of single women ( 62.9 per cent) believe that the treatment they receive from their supervisors negatively influence their overall job satisfaction in their specific directorate. The majority of divorcees/widows ( 55.5 per cent) believe the opposite.

\section{Supervisor traits:}

With regard to whether supervisors have more positive than negative traits, group 3 (divorced/widowed) differs significantly from group 1 (single) and group 2 (married). It appears that the divorced/widowed women are more positive about the traits of their supervisors, in that none of them believe that their supervisors have more negative than positive traits, in comparison to 37 per cent of the single women and 24.1 per cent of the married women.

\section{Day never ends:}

Regarding whether each day of work seems endless, group 1 (single) differs significantly from group 3 (divorced/widowed). It appears that the majority of single women (62.9 per cent) are of the opinion that each day seems like it will 
never end, while the majority of divorcees/widows (61.1 per cent) feel the opposite.

\section{Enjoy:}

With regard to whether they generally do not enjoy their jobs, group 1 (single) differs significantly from group 2 (married) and group 3 (divorced/widowed). It appears that the majority of all three groups generally do enjoy their work. Single women ( 40.7 per cent) are, however, more negative about their jobs than married ( 14.5 per cent) or divorced/widowed ( 5.6 per cent) women.

\section{Force:}

Regarding the question whether they mostly force themselves to go to work, group 1 (single) differs significantly from group 3 (divorced/widowed). It appears that 33.3 per cent of the single women, in comparison to 5.6 per cent of divorced/widowed women have to force themselves to go to work.

\section{Trust:}

With regard to whether supervisors trust them, group 1 (single) differs significantly from group 3 (divorced/widowed). It appears that while the majority of both groups (single: 59.2 per cent; divorced/widowed: 94.5 per cent) believe that their supervisors trust them, more single women (29.6 per cent) than divorcees/widows ( 5.6 per cent) believe that supervisors do not trust them.

\section{Happier than colleagues:}

Regarding the question whether they were happier in their jobs than most other people, group 1 (single) differs significantly from group 2 (married) and group 3 (divorced/widowed). It appears that, although the largest percentage of all three groups agree that they are happier than most other people, the percentage of single women ( 37 per cent) who believe this is far smaller than either the married ( 52.7 per cent) or divorced/widowed ( 70.6 per cent) women who also agreed to this statement. 


\section{CONCLUSIONS AND RECOMMENDATIONS}

The conclusions drawn from the research findings are presented as follows:

\section{Sexual Discrimination:}

The married women in the study generally do not appear to believe that their chances of promotion within the next three years are very good.

\section{Sexual Harassment:}

Single women tend to believe that a woman's submission to or rejection of sexual advances by a person in a higher position may be used as a basis for employment decisions affecting her.

The majority of single women appear to believe that women who are experiencing sexual harassment, will probably tend to stay away from work more often, have less work satisfaction, have a negative image of the department, have less respect for people in positions of authority who "turn a blind eye" and have a negative attitude toward their work environment.

The majority of married women believe that the women who are experiencing sexual harassment will probably have less work satisfaction, have a negative image of the department and a negative attitude towards their work environment.

The majority of divorced/widowed women believe that women experiencing sexual harassment will probably have less work satisfaction, have a negative image of the department, have less respect for people in authority positions who "turn a blind eye" and have a negative attitude towards their work environment.

\section{Job Satisfaction:}

Single womens' perceptions regarding job satisfaction show that the majority of them believe that good suggestions are ignored/negated by supervisors, they would not seize a plausible excuse to stay away from work, the way their supervisors treat them negatively influence their job satisfaction, they often experience that a work day will never end, they generally enjoy their jobs (but to a lesser extent than married and divorced/widowed women), their supervisors trust them and that they are happy in their jobs (also to a lesser extent than married and divorced/widowed women).

Married womens' perceptions of job satisfaction show that they are not satisfied with their job security, they generally think more often of quitting their jobs 
(than single or divorced/widowed women), they are not satisfied with the amount of support and guidance received from supervisors, they are satisfied with the respect received from supervisors and they generally enjoy their jobs. The divorced/widowed womens' perceptions of job satisfaction show that: they believe that many good suggestions are ignored/negated by their supervisors, they are satisfied with the degree of respect and amount of support and guidance received from their supervisors, they are satisfied with the quality of supervision in their jobs, they would not seize a plausible excuse to stay away from work, they believe their supervisors have more positive than negative traits, they strongly believe that their supervisors trust them, they would again choose to work for the department if they could do it all over again and they strongly believe that they are happier in their work than the average woman.

In general, the results of this study seem to indicate that women in the department do not experience sexual discrimination to a large extent. The majority of the women believe that the experiencing of sexual harassment will have a negative impact on job satisfaction, the image of the department (employer), attitude towards their work environment and respect for people in power who do not protect women against harassers. It appears that divorcees/widows are most positive in terms of believing that an experience of sexual harassment will not have too serious an impact on the mentioned behavioural tendencies. Single women showed the strongest indication that sexual harassment would indeed have a consequential effect on the mentioned tendencies.

Pertaining to job satisfaction, single women and women under 30 years of age seem least satisfied with or happy in their work situation, even though married women have indicated that, although they enjoy their work, they most often think of quitting their job. In general, the divorced/widowed women, women over 30 years of age and women who have been working for the department for more than seven years, seem most satisfied with their supervisors and the supervision received. They are satisfied with their jobs and would choose to work in the department if they could do it over again.

Single women and those employed in the department for less than six years, tend to be the least positive of all respondents concerning job satisfaction and their relationship with and treatment by their supervisors.

With the experiences and results gained from this study, the following recommendations are suggested: Special attention should be given to the single women in the department, as they appear to be most negative about their work environment and supervision. In the event of sexual harassment among this group, it appears that they will be most inclined to stay away from work in order 
to avoid such experiences, and their job satisfaction will be most negatively affected.

Work groups should periodically be formed to discuss these issues and to allow female employees the opportunity of airing their views and concerns. It would also be advantageous to grant female employees the opportunity of attempting to find solutions for the manner in which certain problems can be dealt with. At the time of the study, the department did not have a sexual harassment policy in place. Due to the finding that roughly a fifth of the department's female employees seemingly experience sexual harassment, it is evident that this matter needs urgent attention. All women employees should be actively involved in the formulation, implementation and maintenance of such a policy.

Married women, as the majority group among the female employees in the department, appear to be relatively content in their work, but the indication that the majority of them often think of quitting their jobs, should be a concem to the department's management. It thus will be important to identify the particular aspects which negatively affect this group's job satisfaction.

\section{REFERENCES}

I ALBERTYN, C \& WHITE, C. (1994) "Germinating Gender Issues: Gender and Affirmative Action", People Dynamics, 12(10): 57-63.

2 BARON, R.A. \& GREENBERG, J. (1990) Behaviour in Organisations. $\left(3^{\text {rd }}\right.$ ed.) USA, Allyn and Bacon.

3 BEWS, N. (1989) "Women in Business - The Quiet Revolution", Human Resources Management, 5(4): 32-34.

4 BROOMBERG, T. (1993) "Will We be Protected against Sexual Harassment?", Cosmopolitan, July: 14-16.

5 BUBECK, D.E. (1995) Care, Gender and Justice, Oxford, Clarendon.

6 CARD, C. (Ed.). (1999) On Feminist Ethics and Politics, Lawrence, University Press of Kansas.

7 ERWEE, R. (1989) "Women Achievers - Opportunities for Advancement and Empowerment", IPM Journal, 7(10): 3-6.

8 ERWEE, R. (1989) "Beyond the Foundations of Female Advancement", IPM Journal, 7(10): 4-9.

9 FINNEMORE, M. (1998) UPE Students Have their Say about Unfair Discrimination, Port Elizabeth, University of Port Elizabeth Labour Relations Unit.

10 LUBBE, T. (1995) "Do You Come on the Menu?" Student Life, 2(1): 2428. 
11 McCORMICK, E.J. \& ILGEN, D. (1987) Industrial and Organisational Psychology, Great Brittain, Allen \& Unwin.

12 MERCER, E.B. (1986) "What does Equal Opportunity Mean?", IPM Journal, 5(2): 10-12.

13 MORGAN, G.A. \& GRIEGO, O.V. (1998) Easy Use and Interpretation of SPSS for Windows, Mahwah, New Jersey\& London, Lawrence Erlbaum Associates, Publishers.

14 POWELL, G.N. (1989) "The Value of Androgenous Management", SAM Advanced Management Journal, 54(2): 10-13.

15 POWELL, G.N. (1989) "Male/Female Work Roles: What Kind of Future?", Personnel, 66(7): 47-50.

16 PREKEL, T. (1989) "Sexual Harassment: a Deep-rooted Problem", IPM Journal, $7(10): 28-31$.

17 PREKEL, T. (1992) "Sexual Harassment: Guidelines for Management", Focus, 19: 7.

18 RANTALAIHO, L. \& HEISKANEN, T. (1997) Gendered Practices in Working Life, London, Macmillan.

19 RENWICK, A. (1994) "Sexual Harassment: Pointers for Company Policy", Careers Success, 7(8).

20 SILBERMAN, M.T. (1991) Perceptions of Occupational Discrimination against Women in a Commercial Bank, University of Pretoria, Pretoria : Unpublished Honours Thesis.

21 SINCLAIR, M.T. (1996) Gender, Work and Tourism, New York, Routledge.

22 SLABBERT, A. (1990) "Discrimination in the Workplace: A Survey of the State of Affairs in a South African Study", Industrial Relations Journal of S.A., 10(4): 41-45.

23 WERTHER, W.B. \& DAVIS, K. (1985) Personnel Management and Human Resources, ( $2^{\text {nd }}$ ed.) USA, McGraw-Hill Book Company. 